9,10-Phenanthrenequinone（PQ）を誘導体化試薬として用いた ヒト血漿中アセトアルデヒド測定法の検討

末房優子 ${ }^{1}$, 大谷直由 $^{2}$, 和久田浩一 ${ }^{2}$, 佐藤京子 ${ }^{3}$, 倉成正恵 ${ }^{3}$, 上村尚人 ${ }^{2}$

\author{
1大分県警察本部刑事部科学捜査研究所 \\ ８８70-1117 大分県大分市高江西二丁目二番 \\ 2大分大学 医学部 臨床薬理学講座 \\ 干879-5593 大分県由布市㣣間町医大ヶ丘 1-1 \\ 3 大分大学 医学部附属病院 総合臨床研究センター \\ 干879-5593 大分県由布市摤間町医大ヶ丘 1-1
}

\title{
Examination of method for the measurement of acetaldehyde in human plasma by using 9,10-phenanthrenequinone as a derivatizing agent
}

\author{
Yuko Suefusa ${ }^{1}$, Naoyuki Otani², Hirokazu Wakuda ${ }^{2}$, Kyoko Sato ${ }^{3}$, \\ Masae Kuranari ${ }^{3}$ and Naoto Uemura ${ }^{2}$ \\ ${ }^{1}$ Criminal Investigation Laboratory, Oita Prefectural Police H.Q. \\ 2-2, Takaenishi, Oita, Oita, 870-1117 Japan \\ ${ }^{2}$ Department of Clinical Pharmacology and Therapeutics, Oita University Faculty of Medicine \\ 1-1, Hasama-machi idaigaoka, Yufu, Oita, 879-5593 Japan \\ ${ }^{3}$ General Clinical Research Center, Oita University Faculty of Medicine \\ 1-1, Hasama-machi idaigaoka, Yufu, Oita, 879-5593 Japan
}

(Received 11 November 2020; accepted 6 January 2021;

Published online 26 February 2021 in J-STAGE DOI: 10.3408/jafst.804)

Blood acetaldehyde levels are often measured to elucidate individual differences and pharmacokinetics of alcohol metabolism due to the gene polymorphisms of aldehyde dehydrogenase (ALDH2). Blood acetaldehyde levels are of great interest in the field of addictive behaviors, particularly drunk driving behaviors. Conventional blood acetaldehyde concentration measurements are direct and derivatization analyses. Because direct analysis is problematic in that acetaldehyde disappears during storage due to its high volatility and reactivity, derivatization analysis is often performed for acetaldehyde determination in biological samples. The conventional derivatizing method using 2,4-dinitrophenylhydrazine for determination of aldehydes unfortunately produces interfering substances from ketones and carboxylic acids. Therefore, we applied the derivatization method using 9,10-phenanthrenequinone (PQ), reported recently for the interference-free determination of aldehydes. As a result of optimizing the derivatization conditions, a linear calibration relation- 
ship $\left(\mathrm{R}^{2}=0.9994\right)$ in the range of $3-100 \mu \mathrm{M}$ indicated strong results. The limit of detection and quantification was $1 \mu \mathrm{M}$ and $3 \mu \mathrm{M}$, respectively. The intra- and inter-day precision were both below $13.0 \%$ and accuracy was in the range of $-8.5 \%$ to $2.5 \%$. The extraction recoveries of acetaldehyde in human plasma ranged from $80.4 \%$ to $106.8 \%$. The derivative was stable at $4{ }^{\circ} \mathrm{C}$ for 2 days. When acetaldehyde was added in human plasma and derivatized with PQ, acetaldehyde could be quantified by liquid chromatography-mass spectrometry. However, after drinking alcohol, acetaldehyde was measured in healthy subjects with $\left.A L D H 2^{*} 1\right|^{*} 2$, but not with $A L D H 2^{*} 1$ / *1. Acetaldehyde was difficult to detect in subjects with $\left.A L D H 2^{*} 1\right|^{*} 1$, as they are rapid metabolizers of acetaldehyde resulting in low concentrations of acetaldehyde. Acetaldehyde was detected in those subjects with $A L D H 2^{*} 1 /{ }^{*} 2$, however, the measured acetaldehyde levels varied between the analytical methods.

Key words: Acetaldehyde, 9,10-Phenanthrenequinone, Derivatization, Human plasma

\section{緒 言}

日本における飲酒運転による死亡事故は, 飲酒運 転に対する厳罰化などにより減少してきたが，依然 として交通死亡事故の約 6\%が運転者の飲酒による ものであり，事故の減少率は下げ止まり傾向にあ る. また, 飲酒運転の死亡事故率は, 飲酒なしの死 亡事故率と比較すると約7.9倍々極めて高く, 飲酒 運転は交通死亡事故につながる危険性が高いことが 示唆されている1). アルコールの影響下で自動車を 運転した場合, 血液中のアルコール濃度（blood alcohol concentration: BAC）が高くなるにつれて交 通事故の発生リスクが急激に上昇し, BAC $0 \%$ と比 較すると，BAC $0.03 \%$ では交通事故リスクは 1.03 倍, BAC 0.08\%では2.69倍に増加する2). 2002年に 改正された道路交通法では, 処罰対象となる呼気中 アルコール濃度の最低基準が $0.15 \mathrm{mg} / \mathrm{L}$ （BAC 0.03 \%に相当）に引き下げられた.

一方，呼気中アルコール濃度が法規制以下の值と なる飲酒であっても, 自動車運転に非常に大きな影 響を与え, 交通事故発生の危険性を上昇させる可能 性がある報告も散見され ${ }^{3,4)}$, アルコールのみなら ず，代謝物であるアセトアルデヒドや他の物質の影 響もあるのではないかと考えられた。そこで我々 は，アセトアルデヒドの測定に注目した.

経口摂取されたアルコールは，空腹時では約 $25 \%$
が胃から，残りは空腸から吸収される．アルコール の $90 \%$ 以上は代謝され, 残りの $2 \sim 10 \%$ は変化体 のまま尿や汗，呼吸中などに排泄される5)。アル コールは主に酸化系経路によって代謝される。 ず，エタノールは肝蔵でアルコール脱水素酵素 (alcohol dehydrogenase: ADH) などの酵素により 酸化され，アセトアルデヒドが生成される.さらに アセトアルデヒドはアルデヒド脱水素酵素 2 (aldehyde dehydrogenase 2: ALDH2）により，酢酸へと 酸化される。この ALDH2 には遺伝子多型が存在 し，日本人の約 $40 \sim 45 \%$ が ALDH2 の酵素活性が ない遺伝子 $(A L D H 2 * 2)$ をもち，アセトアルデヒ ドの蓄積によって顔面紅潮や低血圧, 動悸などのフ ラッシング反応を生じる6). ALDH2 の酵素活性が ある $A L D H 2^{*} 1$ 遺伝子型の人では, 飲酒後の血液 中アセトアルデヒド濃度が $5 \mu \mathrm{M}$ 以下であるが，酵 素活性が低い $A L D H 2 * 2$ 遺伝子型の人では, 血液 中濃度が $10 \sim 100 \mu \mathrm{M}$ に上昇するとの報告があ $ろ^{7)}$.

血液中アセトアルデヒドの測定方法は，1980年代 までにいくつかのヘッドスペースガスクロマトグラ フィー法（HS-GC）が確立され，飲酒後の濃度が 報告されてきた。 HS-GCでは，全血を除タンパク し，アセトアルデヒドを測定する方法8) と血球を除 いた血漿中のアセトアルデヒドを測定する方法9の 2 つがあるが，前者の一手法である improved per- 
chloric acid（PCA）法が簡便で一般的に使用され ている10,11).

Improved PCA 法は採取した血液を速やかに氷冷 した過塩素酸一生理食塩水溶液に加え, 除タンパク し，その上清をHS-GC装置で分析する。 Improved PCA 法は, 生理食塩水溶液で調整した過塩 素酸を使用することで，除タンパク中に起こるエタ ノールからの非酵素的なアセトアルデヒドの産生を 極力抑える方法であり，血液を過塩素酸に加えてか ら除タンパクを終了するまでの時間が大きく関係 し，できるだけ早く除タンパクをする必要があ る ${ }^{8)}$. 一方，除タンパクした血液を2,4dinitrophenylhydrazine (DNPH) で誘導体化し， 高速液体クロマトグラフ（HPLC）で測定する方法 (DNPH 法) もある12-14).

血液中アセトアルデヒド測定は，アセトアルデヒ ドの揮発性, 反応性が高いことによる採血後の急速 な消失，血液中のエタノールからの非酵素的なアセ トアルデヒド産生，血球に結合したアセトアルデヒ ドの遊離などの問題がある10,11,15). Improved PCA 法では前処理後，バイアルに密封する. バイアルで 保存中にアセトアルデヒドが消失するので測定まで $4{ }^{\circ} \mathrm{C}$ で保管し，速やかに測定する必要がある が8,11), 多数の試料を連続分析する際には HS-GC 装置のオートサンプラー上に注入までの間, 常温で 保管しなければならない。また，DNPHによる誘 導体化法は, 感度は高いが, 操作が煩雑になるため 処理中に消失する可能性があり，アルデヒド類以外 にもケトンなどとも反応することから選択性にそし い. 我々は同時に多数の試料の処理を迅速に行うた め, 前処理が簡便かつ選択性・安定性があり, 新規 のアセトアルデヒド測定法を考案できないかと考 え, 近年報告された血清中の中鎖脂肪族アルデヒド を測定対象として9,10-phenanthrenequinone（PQ） と䣷酸アンモニウムにより誘導体化し，液体クロマ トグラフ質量分析装置（LC-MS）で測定する方法 (PQ 法) ${ }^{16)}$ により従来法の問題の改善を試みた.

PQ 法を血液中アセトアルデヒド測定に適用できる か検討するため，ブランク血漿にアセトアルデヒド を添加し，PQ と酶酸アンモニウムにより誘導体化 を行い，LC-MS で測定した。次に，実際に被験者
にアルコール飲料を飲酒させ, 採取した血液を試料 として，血液中のアセトアルデヒドが測定できるか 検討した.

\section{材料および方法}

\section{1 実験材料}

アセトアルデヒド（無水）, アセトアルデヒド2,4-DNPH 溶液（認証済標準品）は Sigma-Aldrich 社製の試薬を使用し，9,10-phenanthrenequinone (純度97\%), 酢酸アンモニウム（特級），60\%過塩 素酸 (精密分析用)，アセトニトリル (LC/MS 用), ブチルアルデヒド（和光一級）はいずれも富士フイ ルム和光純薬社製の試薬を使用した。2,4dinitrophenylhydrazine（特級）は関東化学社製の 試薬を使用した。 その他の試薬は特級試薬以上の規 格のものを用いた．アセトアルデヒドは，使用直前 に脱気した超純水 (Merck Millipore 社製超純水製 造装置 Milli-Q Integral 5 で製造したもの）で希釈 して用いた。

試験飲料については, 厚生労働省が健康日本 21 に 抢いて，「節度ある適度な飲酒」の量は 1 日平均純 アルコールで約 $20 \mathrm{~g}$ 程度であると提言していること

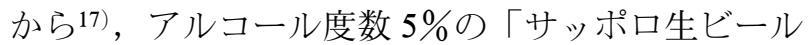
黒ラベル ${ }^{\circledR} 500 \mathrm{ml} 」($ 純アルコール量として19.8 g) を使用した。

アルコール感受性遺伝子検査キットは, イービー エス株式会社から購入した。

\section{2 臨床試験}

本研究の臨床試験は, 大分大学ヒトゲノム研究倫 理審査委員会で承認を得て, UMIN に登録し (UMIN000036717), 大分大学医学部附属病院の CTU (Clinical Trial Unit) 内で研究計画書を遵守

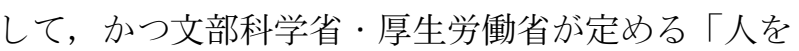
対象とする医学系研究に関する倫理指針」を遵守し て2019年 1 月 1 日〜2020年 3 月31日の間に実施し た。

\section{（1）被験者}

被験者は, 試験参加同意取得日の年齢が20歳以上 55 歳未満, 肥満係数 (BMI) が $18.5 \mathrm{~kg} / \mathrm{m}^{2}$ 以上 30.0 $\mathrm{kg} / \mathrm{m}^{2}$ 以下の体型で, 医師の診察により健康である と判断された日本人の男性を対象とした. アルコー 
ルに対して過敏症の既往歴およびアルコールの代 謝・排泄に影響を及ぼすと思われる疾患・手術歴の ない志願者の中から, 研究責任医師が研究参加に適 格と判断した者を被験者として選択した.

（2）アルコール飲料摂取抢よび採血

被験者に対し，10時間以上の絶食下，試験飲料を 投与した. 試験飲料摂取後 1 時間は絶飲とし, 摂取 後 4 時間は, 絶食とした. 採血は, 試験飲料摂取 前, 試験飲料摂取から 1 時間後および 4 時間後に 行った.

（3）アルコール感受性遺伝子検査

アルコール感受性遺伝子検査キットで被験者の口 腔粘膜を採取し, ADH1B 遺伝子 Arg47His 多型 （rs1229984）とALDH2 遺伝子 Glu48Lys 多型 （rs671）を判定した.

\section{3 測定方法}

臨床試験で被験者から採取した血液中のアセトア ルデヒド測定に PQ 法が適用できるか検討し, 従来 の方法である improved PCA 法, DNPH 法との比 較を行った。

\section{(1) PQ 法}

血漿 $200 \mu \mathrm{L}$ を水冷したアセトニトリル $390 \mu \mathrm{L}$ に

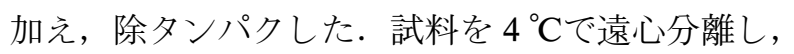
得られた上清に内部標準の $100 \mu \mathrm{M}$ ブチルアルデヒ ドーアセトニトリル溶液 $10 \mu \mathrm{L}$ を添加した。 上清 100 $\mu \mathrm{L}$ をスクリューバイアルに取り, $4 \mathrm{mM} \mathrm{PQ}$ アアセ トニトリル溶液 $50 \mu \mathrm{L}$ および $2 \mathrm{M}$ 酢酸アンモニウ ム一酢酸溶液 $50 \mu \mathrm{L}$ を加え, $70{ }^{\circ} \mathrm{C}$ で 15 分間反応させ た. 反応液を乾固し, LC 初期移動相に溶解後, Merck 社製マイレクス ${ }^{\circledR} \mathrm{PTFE}$ 膜 $0.2 \mu \mathrm{m}$ でフィル ターろ過したものを以下の条件で LC-MSにより測 定し, 内部標準法で定量を行った.

バリデーションについては, アセトアルデヒドを 添加したブランク血漿を用いた。誘導体化した試料 を LC-MS に注入し, 検出下限と定量下限を求め た. 検量線は 5 点 $(3,10,30,60,100 \mu \mathrm{M})$ で作成し, 3 点 $(3,30,100 \mu \mathrm{M})$ の濃度について添加回収率, 正確度および精度（日内・日間変動，それぞれ $\mathrm{n}=$ 5)を求めた.

装置: Agilent Technologies 社製1260 Infinity LC および6540A UHD Accurate Mass Q-TOF LC/
MS, カラム : Agilent Technologies 社製 Poroshell $120 \mathrm{EC}-\mathrm{C} 18 （ 100 \mathrm{~mm} \times 2.1 \mathrm{~mm}$ i.d.，粒子径 2.7 $\mu \mathrm{m})$, ガードカラム: 化学物質評価研究機構製 Lcolumn Guard Column $(5.0 \mathrm{~mm} \times 2.0 \mathrm{~mm}$ i.d., 粒 子径 $5.0 \mu \mathrm{m}$ ), カラム温度 : $25^{\circ} \mathrm{C}$, 移動相 : (A) 20 $\mathrm{mM}$ ギ酸アンモニウム $(\mathrm{pH} 4)$ - $(\mathrm{B})$ メタノール, グラジエント条件：（B） 50\%（０ｍin） $\rightarrow 100 \% （ 3$ $\min , 7 \mathrm{~min}$ 保持), 流速 : $0.2 \mathrm{~mL} / \mathrm{min}$, イオン化 法 : エレクトロスプレーイオン化 (ESI) ポジティ ブモード，測定モード：スキャン $(m / z 100-1000)$

\section{(2) improved PCA 法}

血液 $250 \mu \mathrm{L}$ を水冷した $0.6 \mathrm{M}$ 過塩素酸一生理食塩 水溶液 $1 \mathrm{~mL}$ に速やかに加えた. 試料を $4{ }^{\circ} \mathrm{C} て ゙$ 遠心 分離し，その上清 $500 \mu \mathrm{L}$ をへッドスペースバイア ルに密封し, 以下の条件で HS-GC 装置により測定 し, 絶対検量線法で定量を行った。 また, 血液中の エタノールの定量も同装置で行った.

装置：Perkin Elmer 社製 Turbo Matrix40および 島津製作所製 GC-2010, HS オーブン温度 : 70 ${ }^{\circ} \mathrm{C}$, バイアル保温時間 : $15 \mathrm{~min}$, カラム : Agilent Technologies 社製 HP - INNOWAX $(30 \mathrm{~m} \times 0.32$ $\mathrm{mm}$ i.d., 膜厚 $0.50 \mu \mathrm{m})$, キャリアガス: $\mathrm{He}$, カラ ム流量 : $5 \mathrm{~mL} / \mathrm{min}$, カラム温度 : $40{ }^{\circ} \mathrm{C}(5 \mathrm{~min}) \rightarrow$ $40{ }^{\circ} \mathrm{C} / \mathrm{min} \rightarrow 200^{\circ} \mathrm{C}$, スプリット比 : $1: 5$, 検出器 : 水素炎イオン化検出器, 検出器温度: $220{ }^{\circ} \mathrm{C}$

\section{(3) DNPH 法}

血漿 $100 \mu \mathrm{L}$ を水冷した $3 \mathrm{M}$ 過塩素酸一生理食塩水 溶液 $300 \mu \mathrm{L}$ に加え, 除タンパクを行い， $3 \mathrm{M}$ 酢酸 ナトリウム水溶液 $800 \mu \mathrm{L}$ で液性を $\mathrm{pH} 4$ に調整し た。遠心分離し, 得られた上清に $2 \mathrm{mM}$ DNPH 溶 液（ジメチルスルホキシド： $1 \mathrm{M}$ 塩酸 = 5:1）を $500 \mu \mathrm{L}$ 加え, 室温で10分間反応させた。 反応液 は, メタノール $2 \mathrm{~mL}$ 打よび超純水 $2 \mathrm{~mL}$ でコン ディショニングした固相抽出カートリッジ（ウォー ターズ社製 Sep Pak plus C18）に通液した。カー トリッジを超純水 $1 \mathrm{~mL}, 50 \%$ メタノール水溶液で 順次洗浄し, 過剩な DNPH を除去した. 洗浄後, メタノール $2 \mathrm{~mL}$ で溶出した ${ }^{14)}$. 溶出液を乾固し, HPLC 移動相 $100 \mu \mathrm{L}$ に溶解後, Merck 社製マイレ クス ${ }^{\circledR} \mathrm{PTFE}$ 膜 $0.2 \mu \mathrm{m}$ でフィルターろ過したものを 以下の条件で HPLCにより測定し, 絶対検量線法 
で定量を行った。

装置: Thermo Fisher SCIENTIFIC 社製 Ultimate 3000 HPLC, カラム: 化学物質評価研究機構製 Lcolumn2 ODS（ $150 \mathrm{~mm} \times 4.6 \mathrm{~mm}$ i.d.，粒子径 3.0 $\mu \mathrm{m})$, ガードカラム : 化学物質評価研究機構製 Lcolumn Guard Column $(5.0 \mathrm{~mm} \times 2.0 \mathrm{~mm}$ i.d., 粒 子径 $5.0 \mu \mathrm{m})$, カラム温度 : $40{ }^{\circ} \mathrm{C}$, 移動相 : アセ卜 ニトリル : 水 $(50: 50$, アイソクラティック $)$, 流 速 : $1.0 \mathrm{~mL} / \mathrm{min}$ ，測定波長 : $360 \mathrm{~nm}$

\section{結果および考察}

\section{$1 \quad \mathbf{P Q}$ によるアセトアルデヒド測定方法の検討}

（1）アセトアルデヒド誘導体の定性分析

アルデヒド類を $\mathrm{PQ}$ のような $\alpha$-ジケトンおよび 酢酸アンモニウムと反応させると, フェナントレン キノンジイミンを経て, 反応させたアルデヒドの置 換基を 2 位にもつイミダゾール誘導体が生成す る16,18-21)。このイミダゾール誘導体は，LC-MS の ESI ポジティブモードで効率的にイオン化され，選 択的に定量できると報告されている16). そこで，ア セトアルデヒドに PQ および酢酸アンモニウムを添 加し, 加熱してフェナントロイミダゾール誘導体と L16）（Fig. 1），反応生成物を液体クロマトグラフ 四重極飛行時間型質量分析装置 (LC-Q-TOF-MS) で測定した。その結果，クロマトグラム上の保持時 間7.1分にピークが得られ（Fig. 2a），そのマススペ クトルは $m / z 233.1070$ にインピークを有してお り, $m / z$ 233.1070をプリカーサーイオンとして衝突 誘起解離（コリジョンエネルギー30 V) によるプロ ダクトイオンを測定したところ， $m / z$ 165.0701およ び $m / z$ 192.0801のイオンが観察された（Fig. 2b）. プリカーサーイオンの精密質量から推定した組成式 は $\mathrm{C}_{16} \mathrm{H}_{13} \mathrm{~N}_{2}$ （計算精密質量 $m / z$ 233.1079）であり,
Fig. 1 に示すフェナントロイミダゾール誘導体の一 価のプロトン付加分子イオン $\left([\mathrm{M}+\mathrm{H}]^{+}\right)$と推定 された（Fig. 2c)。 また，プロダクトイオンの精密 質量から組成式および部分構造式を推定すると $m /$ $z 165.0703$ は $\mathrm{C}_{13} \mathrm{H}_{9}$ （計算精密質量 $m / z$ 165.0704）, $m / z 192.0801$ は $\mathrm{C}_{14} \mathrm{H}_{10} \mathrm{~N}$ （計算精密質量 $m / z$ 192.0813）と考えられた（Fig. 2c）. El-Maghrabey らは脂肪族アルデヒドの $\mathrm{PQ}$ 誘導体の $[\mathrm{M}+\mathrm{H}]^{+}$を プリカーサーイオンとし, 衝突誘起解離させて測定 すると $m / z 164.8$ および $m / z$ 192.0のプロダクトイ オンが観察されると報告していることから ${ }^{16)}$, 保持 時間7.1分のピークは PQ-アセトアルデヒド誘導体 と判断した.

(2) 測定対象試料の検討

測定対象試料として全血と血漿について検討し た. 全血を直接除タンパクし, PQ 法により誘導体 化したものは，血漿を除タンパクしたものに比べて 回収率が悪く，測定值のばらつきが大きかったため (データは示さず)，血漿試料を測定対象試料とし た. 全血を直接除タンパクする際に血球成分への結 合などの影響があったと考えられた。なお， DNPH 法についても同様であったため, 血漿試料 を用いた。

\section{（3）誘導体化反応条件の最適化}

アセトアルデヒド標準液に $1 \sim 8 \mathrm{mM}$ の範囲で調 整した $\mathrm{PQ}$-アセトニトリル溶液および $0.1 \sim 4 \mathrm{M}$ の 範囲で調整した酢酸アンモニウム一酢酸溶液を加 え， $100{ }^{\circ} \mathrm{C} て ゙ 30$ 分間加熱した結果，Fig. 3 に示すよ うに $\mathrm{PQ}$-アセトニトリル溶液の濃度が $2 \mathrm{mM}$ 以 上, 酢酸アンモニウム一酶酸溶液の濃度が $2 \mathrm{M}$ 以上 で PQ-アセトアルデヒド誘導体の検出強度が同程 度であったが, 検出強度が最大であった $4 \mathrm{mM} \mathrm{PQ}$ 一アセトニトリル溶液, $2 \mathrm{M}$ 酢酸アンモニウム一酢酸

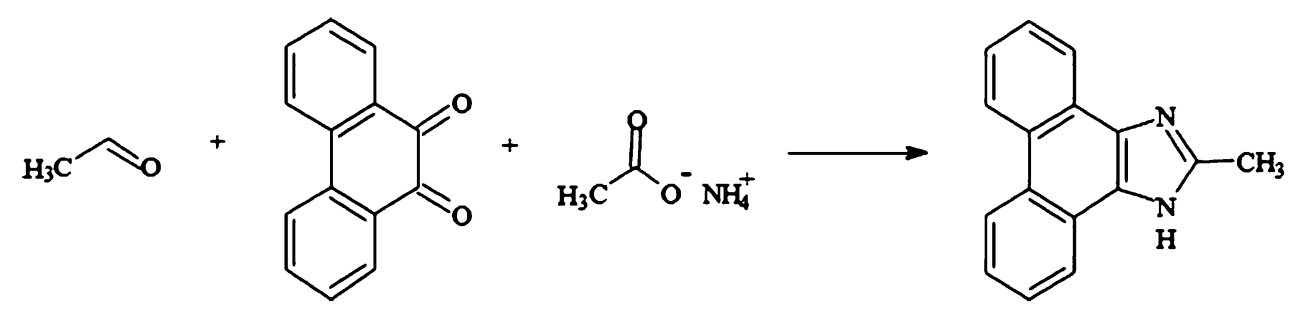

Fig. 1 Reaction scheme for acetaldehyde derivatized by PQ and ammonium acetate ${ }^{16)}$. 


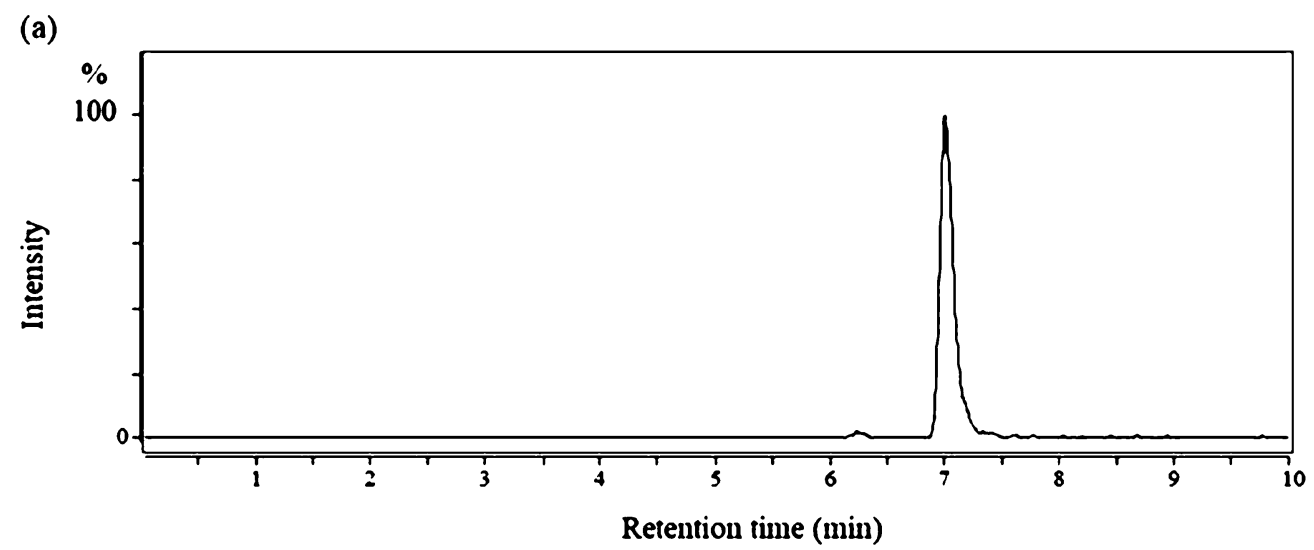

(b)

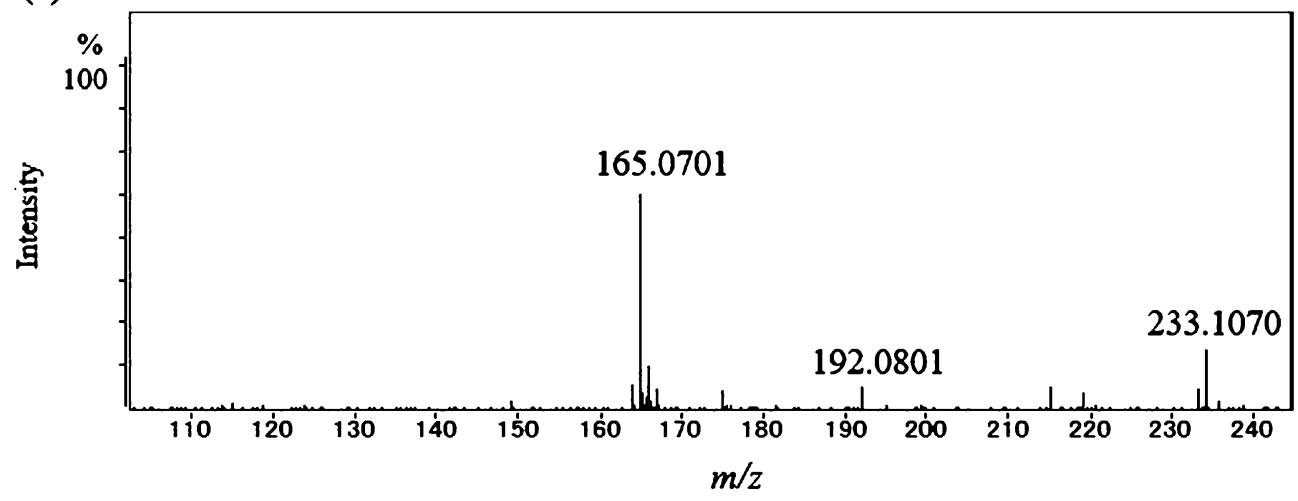

(c)

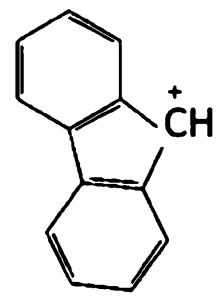

$\mathrm{C}_{13} \mathrm{H}_{9}$ $m / 2165.0704$<smiles>Nc1[c-]c2ccccc2c2c1CCC=C2</smiles>

$\mathrm{C}_{14} \mathrm{H}_{10} \mathrm{~N}$ $m / z 192.0813$

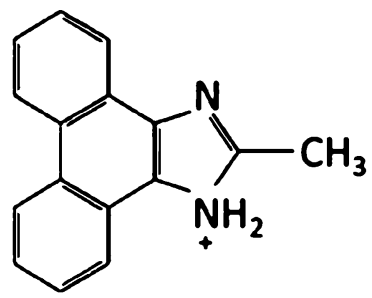

$\mathrm{C}_{16} \mathrm{H}_{13} \mathrm{~N}_{2}$ $m / 2233.1079$

Fig. 2 Detection of the PQ-acetaldehyde derivative using LC-Q-TOF-MS. (a) Extracted ion chromatogram $(m$ $/ z$ 233.1079), (b) product ion spectrum of the peak detected at $7.1 \mathrm{~min}$ (precursor ion: $m / z 233.1070$, collision energy: $30 \mathrm{~V}$ ) and $(\mathrm{c})$ the proposed structures of the fragment ions ${ }^{16}$.

溶液の条件に決定した。ささに，反応温度および反 応時間について検討した結果, Fig. 4 に示すように

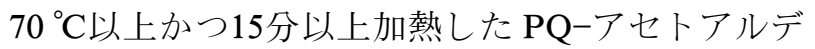
ヒド誘導体の検出強度に変化は見られなかったの で, 反応温度は $70{ }^{\circ} \mathrm{C}$, 反応時間は 15 分間が最適で あると考えられた。

(4) 分析バリデーション

アセトアルデヒドを添加したブランク血漿を前処 理し，PQ法により誘導体化して得られたアセトア
ルデヒド誘導体について分析バリデーションを行っ た。

飲酒後の血液中アセトアルデヒド濃度は, $A L D H 2^{*} 1$ 遺伝子型の人では $1 \sim 2 \mu \mathrm{M}$ 程度であ り，ALDH $2^{*} 2$ 遺伝子型の人では血液中濃度が 10 $100 \mu \mathrm{M}$ に上昇するという報告があることから，血 液中アセトアルデヒド測定では $1 \sim 100 \mu \mathrm{M}$ の濃度 を測定できるかが問題となる7).アセトアルデヒド は試薬や環境中に広く存在するため, 前処理中の混 


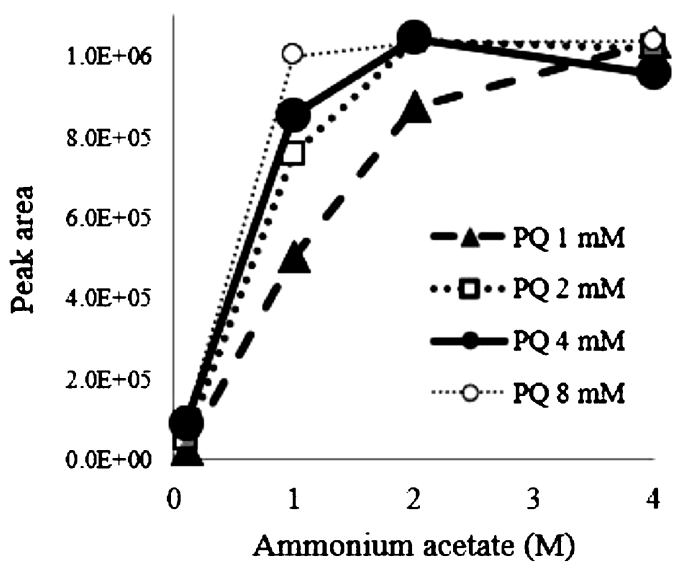

Fig. 3 Derivatization of acetaldehyde with various PQ concentrations $(1,2,4$ and $8 \mathrm{mM})$ and various ammonium acetate concentrations $(0.1,1,2$ and $4 \mathrm{M}$ ).

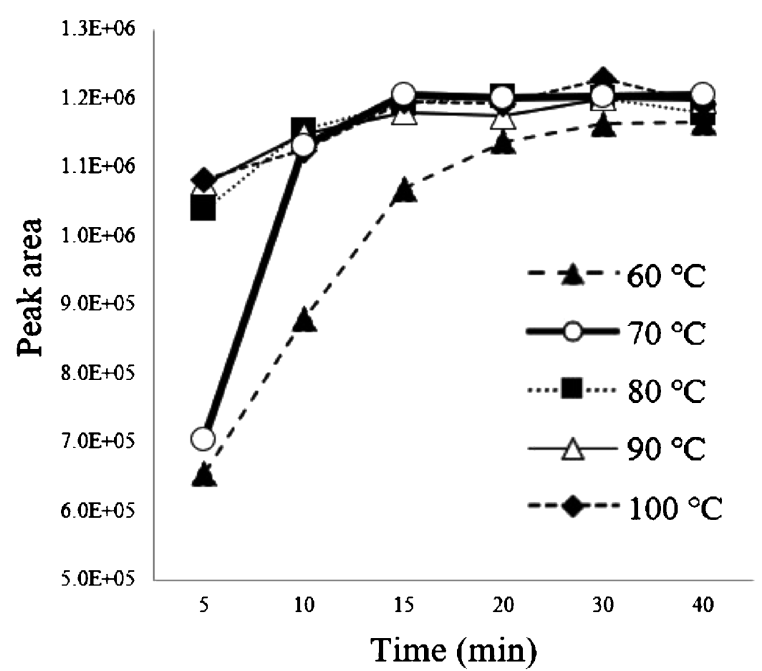

Fig. 4 Derivatization of acetaldehyde with various reaction times $(5,10,15,20,30$ and $40 \mathrm{~min})$ and various temperature conditions $(60,70,80,90$ and $100{ }^{\circ} \mathrm{C}$ ).
入を完全に避けることはできず，ブランク試験を 行ったところ, 微量のアセトアルデヒド誘導体が検 出された。 ブランク值から求めた検出下限は 1 $\mu \mathrm{M}$ ，定量下限は $3 \mu \mathrm{M}$ であった。検量線は $3 \sim 100$ $\mu \mathrm{M}$ の範囲で良好な直線性（ $\mathrm{y}=0.070 \mathrm{x}+0.2364, \mathrm{R}^{2}$ =0.9994）を示した. Table 1 に示すように回収率， 正確度および精度も良好な結果が得られた。

なお，今回検討したimproved PCA 法および DNPH 法の定量範囲は，それぞれ $1 \sim 100 \mu \mathrm{M}$ およ び 2〜80 $\mu \mathrm{M}$ であった.

（5）選択性および安定性

アルデヒドの誘導体化を行う DNPH 法は，アル デヒドだけではなくケトンやカルボン酸とも反応 し，選択性に乏しいが，PQ 法では，アセトンのよ うなケトン類，反応触媒として用いている酢酸によ る妨害は見られないと報告されている16)。実際にア セトンを添加したブランク血漿を PQ 法により誘導 体化させて分析したところ，アセトンに由来する妨 害ピークは見られず（データは示さず）, PQ 法は アセトアルデヒドに対する選択性があると確認され た.

また，Fig. 5 に示すようにアセトアルデヒド誘導 体は $4{ }^{\circ} \mathrm{C}$ 保管で 2 日間安定であり，オートサンプ ラー上で安定した連続分析が可能であることが示さ れた。

\section{2 臨床試験による検討}

（1）アルコール感受性遺伝子検査の結果

血漿に添加したアセトアルデヒドは PQ 法により 測定できることを確認した.さらに, 飲酒後, 生体 内で代謝されたアセトアルデヒドの測定に適用でき るか検討した。臨床試験では，治療中の疾患がな く，医薬品を服用していない者を選択し，条件を満 たす 4 名（男性，年齢：44.5 \pm 5.1 歳, 体重：66.4

Table 1 The recovery, accuracy and precision data of acetaldehyde spiked into blank plasma $(n=5)$.

\begin{tabular}{|c|c|c|c|c|c|}
\hline \multirow{2}{*}{$\begin{array}{c}\text { Spiked } \\
\text { concentration } \\
(\mu \mathrm{M})\end{array}$} & \multirow{2}{*}{$\begin{array}{c}\text { Recovery } \\
(\%)\end{array}$} & \multicolumn{2}{|c|}{ Intraday } & \multicolumn{2}{|c|}{ Interday } \\
\hline & & $\underset{(\%)}{\text { Accuracy }}$ & $\begin{array}{c}\text { Precision } \\
(\%)\end{array}$ & $\underset{(\%)}{\text { Accuracy }}$ & $\begin{array}{c}\text { Precision } \\
(\%)\end{array}$ \\
\hline 3 & 83.7 & 0.4 & 6.1 & -8.5 & 13.0 \\
\hline 30 & 80.4 & -5.1 & 1.3 & 1.0 & 3.5 \\
\hline 100 & 106.8 & 0.7 & 1.0 & 2.5 & 2.3 \\
\hline
\end{tabular}




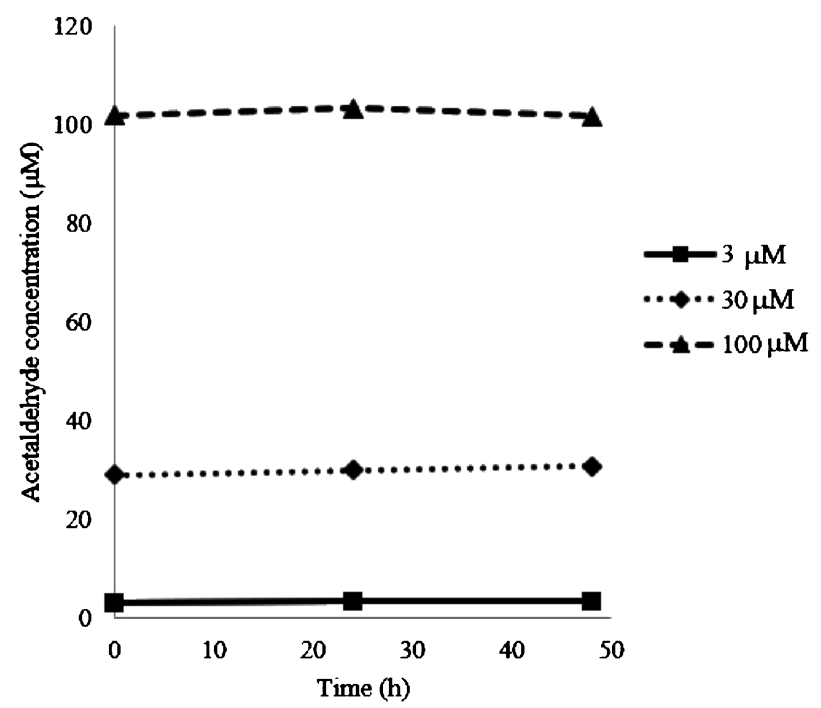

Fig. 5 Stability of the PQ-acetaldehyde derivative at $4{ }^{\circ} \mathrm{C}$.

Table 2 ADH1B and ALDH2 genotype of the subjects.

\begin{tabular}{|c|c|c|c|c|}
\hline \multirow{2}{*}{$\begin{array}{l}\text { Subject } \\
\text { number }\end{array}$} & \multicolumn{2}{|c|}{ ADH1B } & \multicolumn{2}{|c|}{ ALDH2 } \\
\hline & Genotype & Activity & Genotype & Activity \\
\hline 1 & $* 2 / * 2$ & \multirow{2}{*}{ High activity } & $*_{1} 1 / *_{1}$ & \multirow{3}{*}{ Active } \\
\hline 2 & $*_{2} / *_{2}$ & & $*_{1} / *_{1}$ & \\
\hline 3 & $*_{1} / *_{2}$ & \multirow{2}{*}{ Active } & $*_{1} / *_{1}$ & \\
\hline 4 & $*_{1} / *_{2}$ & & $*_{1} / *_{2}$ & Low activity \\
\hline
\end{tabular}

$\pm 3.3 \mathrm{~kg}, \mathrm{BMI}: 22.7 \pm 0.4)$ を被験者とした．被験 者のアルコール感受性遺伝子検査の結果を Table 2 に示す。ALDH2の遺伝子タイプは活性型 $\left(A L D H 2^{*} 1 /{ }^{*} 1\right.$ 型 $)$ が 3 名, 低活性型 $\left(A L D H 2^{*} 1 /\right.$ *2 型) が 1 名であった.

(2) 血液試料の測定結果

Fig. 6 に示すように全ての被験者は飲酒開始から 1 時間後の血液中エタノール濃度が $0.3 \mathrm{mg} / \mathrm{mL}$ 程度 となり, 飲酒開始から 4 時間後で $0.03 \mathrm{mg} / \mathrm{mL}$ 程度 まで低下した。

in vitroで血液とエタノールを混合すると非酵素 的な酸化により微量のアセトアルデヒドが産生され る．予備実験として，ブランク血液にエタノールを 添加して0.3, $0.03 \mathrm{mg} / \mathrm{mL}$ になるように調整したも のを前処理し, エタノールからの非酵素的な産生分

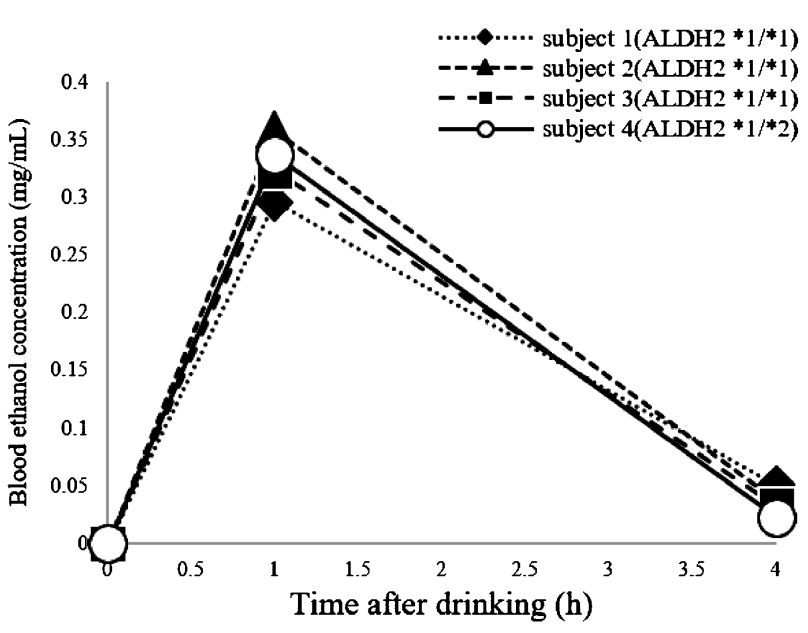

Fig. 6 Blood ethanol concentrations after drinking in each subject measured by HS-GC.

を調べ，試料のアセトアルデヒド濃度から減算し た。

$\left.A L D H 2^{*} 1\right|^{*} 1$ 型被験者 3 名の飲酒開始から 1 時 間後抢よび 4 時間後の血液中アセトアルデヒド濃度 は，いずれの方法でも定量下限值以下であった。 ア セトアルデヒドの代謝が速い $A L D H 2^{*} 1 /{ }^{*} 1$ 型被験 者では, 今回の飲酒量により生成されるアセトアル デヒドの量は少なく，低濃度領域では，非酵素的な アセトアルデヒド産生分を減算すると不検出になる ものもあり，測定が困難であった。

$A L D H 2^{*} 1 / * 2$ 型被験者 1 名の血液中アセトアル デヒド濃度は, PQ 法では飲酒開始から 1 時間後が $3.3 \mu \mathrm{M} ， 4$ 時間後は定量下限值以下であった. Improved PCA 法では飲酒開始から 1 時間後が 7.9 $\mu \mathrm{M} ， 4$ 時間後が $4.0 \mu \mathrm{M}$ であった。 DNPH 法では飲 酒開始から 1 時間後が $3.6 \mu \mathrm{M}, 4$ 時間後は定量下限 值以下であった。 $A L D H 2^{*} 1 /{ }^{*} 2$ 型は $A L D H 2 * 1 /{ }^{*} 1$ 型よりもアセトアルデヒドの代謝が遅いため, $A L D H 2^{*} 1 /{ }^{*} 2$ 型被験者の飲酒から 1 時間後の血液 中アセトアルデヒド濃度は，いずれの方法でも測定 できたと考えられた。

$A L D H 2^{*} 1 /{ }^{*} 2$ 型被験者の飲酒開始から 1 時間後 および 4 時間後の血液中アセトアルデヒド濃度を測 定法別に比較した（Fig. 7). PQ 法は DNPH 法と 近い值を示したが，improved PCA 法と比較すると 測定值に 2 倍程度の差が見られた。 


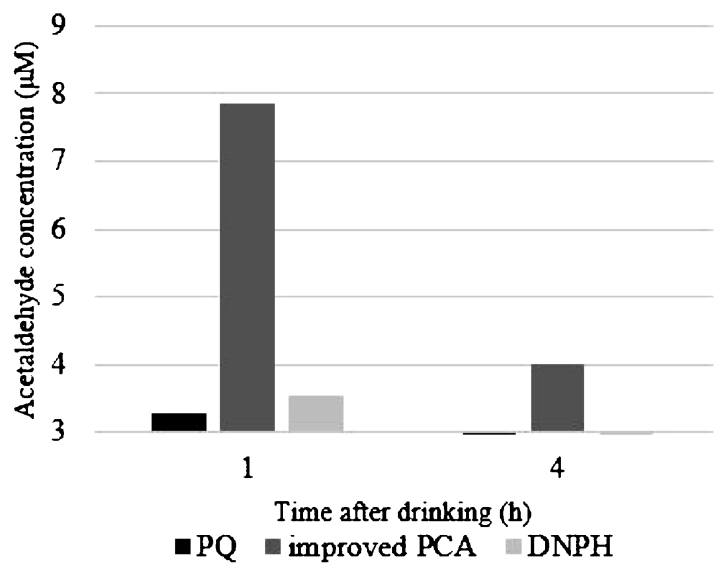

Fig. 7 Comparison of acetaldehyde concentrations after drinking in subject 4 with $A L D H 2^{*} 1 /{ }^{*} 2$ measured by PQ method, improved PCA method and DNPH method.

PQ 法と DNPH 法では，全血を直接除タンパク すると回収率や精度が悪かったため，採血後に血球 成分を遠心分離して除去し，得られた血漿について 誘導体化を行った．血漿を測定する方法では前処理 中の非酵素的なアセトアルデヒド産生の影響を抑え ることができるが，遠心分離に時間がかかるとアセ トアルデヒドが激減してしまう欠点がある ${ }^{9,10)}$. 今 回の結果から，PQ 法と DNPH 法では主に遠心分 離中のアセトアルデヒド消失があったと考えられ た。 な，アセトアルデヒドは反応性が高く，血液 中に存在するシステインなどの SH 化合物・アミン 類・アミノ酸と結合したり，血球に存在するアルデ ヒド脱水素酵素により酸化されたりするため, 試料 を採取してから測定するまで時間がかかると消失す る可能性がある11).アセトアルデヒド消失を防ぐた め，採血後の遠心分離を迅速に行い， $3 \mu \mathrm{M}$ 以下の 低濃度域を測定できるように，誘導体化するまでの 時間を短縮し，ブランク值を低減させるなど前処理 方法を再検討する必要が示唆された。

\section{結 語}

PQ を誘導体化試薬として用いる脂肪族アルデヒ ドの測定方法を血液中のアセトアルデヒド測定に適 用できるか検討し，実際にアルコール飲料を摂取し た被験者の血液中アセトアルデヒド測定を行った。
ブランク血漿にアセトアルデヒドを添加し， PQ で誘導体化したものについては，アセトアルデヒド 誘導体が検出され，LC-MSにより定量が可能で あった。

一方，アルコール飲料を摂取した被験者の血液の 測定については，アセトアルデヒドの代謝が遅い $A L D H 2^{*} 1 /{ }^{*} 2$ 型の被験者の血液でアセトアルデヒ ドを測定することができたが，今回検討した方法で は，採血後に全血をただちに除タンパクする improved PCA 法と比較して低い值を示したため, 採 血から遠心分離により血漿を得るまでの時間にアセ トアルデヒドの消失があったと考えられた。

$\mathrm{PQ}$ 法は，簡便な前処理でアセトアルデヒドを測 定可能であり，選択性や安定性があることも確認さ れた．血液中アセトアルデヒド測定の難点である採 血後の前処理について今後さらに検討することで, 新たな血液中アセトアルデヒド測定法の一つとして 提案できると考えられた.

\section{利益相反}

申告すべき利益相反はない。

\section{文 献}

1）警察庁交通局，令和元年中の交通死亡事故の 発生状況及び道路交通法違反取締り状況等につ いて, available from [https://www.e-stat.go.jp /], accessed Nov 5, 2020.

2) Blomberg, R. D., Raymond C. P., Herbert M., Marcelline B. and Dary F., Crash risk of alcohol involved driving: a case-control study. Dunlap and Associates, Connecticut, 2005.

3）科学警察研究所交通安全研究室, 低濃度のア ルコールが運転操作等に与える影響に関する調 查研究, available from [https://www.npa.go.jp / koutsuu / kikaku/insyuunten/ kakeiken-kenkyu. pdf], accessed Nov 5, 2020.

4) 中村信次, アルコール摂取が認知課題遂行に 及ぼす影響一飲酒運転はドライバーの認知判断 能力を如何に阻害するのか? 一, 日本福禅大学 情報社会科学論集，10, 21-26, 2007.

5) Lieber C. S., Metabolism of alcohol. Clin. 
Liver Dis., 9, 1-35, 2005.

6) Higuchi S., Matsushita S., Muramatsu T., Murayama M. and Hayashida M., Alcohol and aldehyde dehydrogenase genotypes and drinking behavior in Japanese. Alcohol. Clin. Exp. Res., 20, 493-497, 1996.

7) Mizoi Y., Tatsuno Y., Adachi J., Kogame M., Fukunaga T., Fujiwara S., Hishida S. and Ijiri I., Alcohol sensitivity related to polymorphism of alcohol-metabolizing enzymes in Japanese. Pharmacol. Biochem. Behav., 18, 127-133, 1983.

8) Eriksson C. J. P., Mizoi Y. and Fukunaga T., The determination of acetaldehyde in human blood by the perchloric acid precipitation method: the characterization and elimination of artefactual acetaldehyde formation. Anal. Biochem., 125, 259-263, 1982.

9) Pikkarainen P. H., Salaspuro M. P. and Lieber C. S., A method for the determination of "free", acetaldehyde in plasma. Alcohol. Clin. Exp. Res., 3, 259-261, 1979.

10）福永龍繁, 山本秀孝, 種子島章男, ヒト血液 中アセトアルデヒド濃度測定法, 日本アルコー ル・薬物医学会雑誌, 33, 190-199, 1988.

11）大洞弓子，藤宮龍也，血中アルコール及びア セトアルデヒド測定法とその留意点, 臨床検 査，47，627-631, 2003.

12) Lynch C., Lim M., Thomas M. and Peters T. J., Assay of blood and tissue aldehydes by HPLC analysis of their 2,4-dinitrophenylhydrazine adducts. Clin. Chim. Acta, 130, 117-122, 1983.

13) Pezzoli C., Galli-kienle M., Padova C. D. and Stramentinoli G., HPLC method for the evaluation of blood acetaldehyde without ethanol interference. J. Liq. Chromatogr., 7, 765-778, 1984.

14) Kozutsumi D., Arita M., Kawashima A., Adachi M. and Takami M., An improved method for acetaldehyde determination in blood by highperformance liquid chromatography and solidphase extraction. J. Chromatogr. Sci., 40, 477482, 2002.

15) Fukunaga T., Sillanaukee P. and Eriksson C. J. P., Problems involved in the determination of endogenous acetaldehyde in human blood. Alcohol Alcohol., 28, 535-541, 1993.

16) El-Maghrabey M., Kishikawa N. and Kuroda $\mathrm{N}, 9,10$-Phenanthrenequinone as a mass-tagging reagent for ultra-sensitive liquid chromatographytandem mass spectrometry assay of aliphatic aldehydes in human serum. J. Chromatogr. A, 1462, 80-89, 2016.

17）厚生労働省, 健康日本21（アルコール）, available from [https://www.mhlw.go.jp/www1/ topics/kenko21_11/], accessed Nov 5, 2020.

18) Davidson D., Weiss M. and Jelling M., The action of ammonia on benzil. J. Org. Chem., 2, 319-327, 1937.

19）境野芳子, 都丸芳子, 柿沢 寛, 楠見武徳, 9,10ーフェナントレンキノンと第一級アミンの反 応によるフェナントロイミダゾールおよびフェ ナントロオキサゾール誘導体の生成, 日本化学 会誌, 10, 1587-1590, 1976.

20) Bu L., Sawada T., Shosenji H., Yoshida K. and Mataka S., Crystallographic structures and solid fluorescence behaviors of crystals of a 2-(9-anthryl)phenanthroimidazole-type clathrate host, Dyes Pigments, 57, 181-195, 2003.

21) Kishikawa N., Wada M., Ohba Y., Nakashima K. and Kuroda N., Highly sensitive and selective determination of 9,10-phenanthrenequinone in airborne particulates using high-performance liquid chromatography with pre-column derivatization and fluorescence detection, J. Chromatogr. A, 1057, 83-88, 2004. 